\title{
EXPERIMENTAL STUDY ON HEAT TRANSFER OF PULSATING FLOW ENHANCED THE PLATE HEAT EXCHANGER
}

CQian H., ORCID: 0000-0002-6638-6706, Jiangsu University of Science and Technology, Ogarev Mordovia State University, Saransk, Russia, qianzhengyu001@ sina.com CKudashev S., SPIN-code: 4763-0003, Ph.D., Ogarev Mordovia State University, Saransk, Russia, kudaschev@mail.ru CPlotnikov V., ORCID: 0000-0002-0987-9897, Ogarev Mordovia State University, Saransk,Russia,vitya.plotnikov.1995@mail.ru

\section{ЭКСПЕРИМЕНТАЛЬНОЕ ИССЛЕДОВАНИЕ ИНТЕНСИФИКАЦИИ ТЕПЛОПЕРЕДАЧИ В ПЛАСТИНЧАТОМ ТЕПЛООБМЕННИКЕ ПРИ ПУЛЬСИРУЮЩЕМ ТЕЧЕНИИ ТЕПЛОНОСИТЕЛЯ}

(СЦянь X., ORCID: 0000-0002-6638-6706, Цзянсуский университет науки и технологии,

Национальный исследовательский Мордовский государственный университет им. Н. П. Огарева, г. Саранск, Россия, qianzhengyи001@ sina.com

(CКудашев С. Ф., SPIN-код: 4763-0003, канд. техн. наук, Национальньй исследовательский Мордовский государственный университет им. Н. П. Огарева,

2. Саранск, Россия, kudaschev@mail.ru

СПлотников В. А., ORCID:0000-0002-0987-9897, Начиональный исследовательский Мордовский государственный университет им. Н. П. Огарева,

2. Саранск, Россия,vitya.plotnikov.1995@mail.ru

Abstract. We conducted two sets of experiments, one is under steady-state conditions and the other under pulsating conditions. We focused on measuring the heat transfer characteristics of plate heat exchangers under different pulsation conditions. In the experiment, we control the mass flow of the hot fluid to circulate at a rate of $0.722 \mathrm{~kg} / \mathrm{s}$. The mass flow rate of the cold fluid is $0.05-0.18$ $\mathrm{kg} / \mathrm{s}$, and the pulsation frequency is $0.45-2.23 \mathrm{~Hz}$. We measured different mass flows at different pulsation frequency. The data analysis shows that when the pulsation frequency is $1.78 \mathrm{~Hz}$, the heat transfer coefficient reaches a maximum of $4415.73 \mathrm{w} /\left(\mathrm{m}^{2} \cdot \mathrm{k}\right)$, and the corresponding cold fluid mass flow rate is $0.155 \mathrm{~kg} / \mathrm{s}$, and compared with the heat transfer characteristics of the plate heat exchanger under steady flow, it is found that the average increase in the heat transfer coefficient during the transition to the pulsating mode was $20 \%$.

Аннотация. Статья посвящена исследованию теплопередачи при пульсирующем режиме течения теплоносителя. В данной статье проведено две серии экспериментов в пульсирующем и стационарном режимах. Эксперименты проводились при различных режимах пульсаций. Расход греющей жидкости поддерживался постоянным 0,722 кг/с. Изменялись массовый расход нагреваемого теплоносителя от $0,05-0,18$ кг/с, и частота пульсаций - 0,45-2,25 Гц. Анализ полученных данных показывает что при частоте пульсаций 1,78 Гц, коэффициент теплопередачи достигает максимума 4415,73 Вт/( $\left.{ }^{2 \circ} \mathrm{C}\right)$ соответствующий массовый расход жидкости составлял 0,155 кг/с. При этом среднее увеличение коэффициента теплопередачи при переходе к пульсирующему режиму составило $20 \%$ 
Keyword: plate heat exchanger, pulsating flow, heat transfer coefficient, Nusselt number, Reynolds number, enhancement factor.

Ключевые слова: пластинчатый теплообменник, пульсирующий поток, коэффициент теплопередачи, число Нуссельта, число Рейнольдса, факторы эксперимента.

\section{Introduction}

Heat transfer under pulsating flow has applications in various fields and industrial engineering. For example, pulsating flow is used in gas turbines, Stirling engines, nuclear power systems, biological fluid systems, electronic heat pipes and other electronic devices, so pulsating fluid heat transfer plays an important role in modern industrial applications, especially in the field of micro-macro engineering [1-2]. According to the existing literature, the effect of pulsationenhanced heat transfer has the following conclusions: First, the effect of pulsating flow enhancing heat transfer is not obvious; second, the pulsating flow will deteriorate flow and weaken heat transfer; the third pulsating has no effect on flow and heat transfer [3].

The factors affecting the heat transfer effect of pulsating fluid are Reynolds number, pulsation frequency, pulsation amplitude, pulsation speed, the geometry of flow channel, the installation position of pulsation generator, pulsation waveform, fluid medium, inherent physical parameters of the system, etc. The methods of study heat transfer characteristics of fluids mainly include experimental methods and numerical simulation methods. Effect of Reynolds Number on Pulsating Heat Transfer Mohammad Jafari used Boltzmann lattice method to study the factors affecting pulsating heat transfer under Reynolds numbers of 50,100, 150 and Prandtl number of 3.103. The main factor affecting pulsating heat transfer is the pulsation speed, there is an optimal pulsation speed, and then the heat transfer rate is the largest. At high pulsation frequency, the heat transfer rate begins to decrease; applying a pulsation velocity gradient at low frequency and low Reynolds number will cause the heat transfer to weaken. Low frequency, low amplitude, high Reynolds number, a pulsation velocity gradient is applied to enhance heat transfer, and pulsating flow is used as an active heat transfer enhancement technology. The heat transfer enhancement depends mainly on the Reynolds number, and the pulsation speed also plays a very important role in the heat transfer enhancement process [3]. According to the dimensionless pulsation frequency, we can divide the flow pattern into the following three types (Womersley number, Wo): quasi-steady state (Wo < 1.6), intermediate state (Wo = 1.6-27.6), and inertial dominance (Wo > 27.6) characteristic flow state. The quasi-steady state process can be observed in a single pulsation cycle, in the intermediate flow state, the viscous force and the inertial force are equal, and the inertia-dominated flow state is mainly controlled by the inertial force associated with the flow artery motion [2].

E. Zohir [4] studying the downstream and countercurrent flow heat transfer characteristics of concentric tube hot and cold fluid under pulsating conditions under high Reynolds number, the Nusselt number increases by $20 \%$ under downstream conditions, and the Nusselt number increases 90\% under countercurrent conditions, the correlation for the average Nusselt number is confirmed to be $12 \%$ of the maximum error at different pulsation frequencies and Reynolds numbers.

In different flow path structures we can observe various trends, fluid flows in the ribbed channel [5-6], fluid flows through the turbulent cylinder [7-9], and the fluid flows through different spoiler elements [10], the fluid flows in the wave-shaped channel [11], showing significantly enhanced heat transfer effect under pulsation conditions, different channel structures and spoiler elements will affect the formation and detachment of vortex streets, vortex and pulsation act together on fluid heat transfer.

Shuai et al. [12] placed the pulsation generator in the upstream part of the system, with a 
Reynolds number between 150 and 1000, a frequency between 0 and $2 \mathrm{~Hz}$, and a pulsation amplitude range from $155 \mathrm{~mm}$ to $400 \mathrm{~mm}$. The effect of pulse perturbation on the convective heat transfer of the coaxial cylindrical tube heat exchanger, the experiment found that the pulse can significantly increase the heat transfer coefficient by $300 \%$.

West and Taylor [13] experimentally studied the effect of the pulsation on the heat transfer coefficient of water in a long horizontal tube of a steam-water heat exchanger. The pulsating stream of water was pulsated by a reciprocating pump, located upstream, Reynolds number was varied from 30,000 to 85,000 and pulsation frequency was fixed at $1.6 \mathrm{~Hz}$. The amplitude ratio varied from 1.00 to 1.56 . They recorded an increase between $60 \%$ to $70 \%$ in the heat transfer coefficient at an amplitude ratio of 1.42 .

Darling [14] reported an increase of $90 \%$ in the heat transfer coefficient, at a Reynolds number of 6000 and a pulsation rate of 160 cycles $/ \mathrm{mm}$, when pulses were introduced upstream of the heaters. No improvement in the heat transfer coefficient was observed with the pulsegenerator installed at downstream of the heater.

A. E. Zohir [4] conducted an experimental study on concentric double-pipe heat exchangers, hot water $\left(40-70^{\circ} \mathrm{C}\right)$ was passed through the inner pipe with fixed mass flow rate (Reynolds number $\approx 10,200$ ) while cold water was passed through the annulus with Reynolds number ranging from 2,000 to 10,200 and exposed to pulsation. The investigation is performed for pulsation frequency ranged from 0 to $40 \mathrm{~Hz}$ while the amplitude was kept constant by fixing the pulsegenerator at heat exchanger outlet. The maximum enhancement in Nusselt number for the downstream flow was about $20 \%$ while it was about $90 \%$ for countercurrent flow.

A. E. Zohir [6] studied concentric double-tube heat exchangers with a Reynolds number of 4000-12000. Cold water flows in the annular passage in the middle of the tank wall. The cold water and hot water exchange heat in the form of counterflow and the outer wall of the inner tube is wound around the heating coil. The effects of Reynolds number, Nusselt number and friction factor are discussed by adjusting the spacing between the coils.

Zhang [15] Simulate under three different pulsating waveforms Three types of pulsating waveforms including square-wave, sinusoidal-wave and semi-sinusoidal, Three different pulsating waveforms are used as inlet conditions, Simulation result Compared with steady state flow at the same mass flow rate, The results show that introducing pulsating flow can significantly improve the overall thermal performance. In addition, the pulsating inlet with sinusoidal wave led to the highest heat transfer coefficient among the three types of pulsating inlet conditions in consideration. Therefore, this pulsating inlet condition is more beneficial to strengthening the heat transfer during the practical application.

M. Rahgoshay [1] Numerical simulation of the effect of nanofluids on pulsating heat transfer under different pulsating parameters (Amplitude, Strouhal and Reynolds numbers) and volume fractions of nanoparticles for unsteady flow, Simulation result display increasing both the frequency and amplitude leads to a slight increase in Nusselt number but by increasing Reynolds and volume fraction, more rate of heat transfer is observed.

Mehta [16] studied experimental research; it is found that the laminar pulsating flow has no significant effect on the overall heat transfer characteristics in the measured frequency range compared with the steady-state flow with the time-averaged flow Reynolds number. This effect is limited, mainly refers to the development length of the channel, so heat transfer enhancement due to periodic pulsating flow is questionable, and at best, rather limited.

Chattopadhyay [17] studied the heat transfer in a circular isothermal duct with imposed flow pulsation at the inlet. The Reynolds number is fixed at 200, and the amplitude is less than 1.0, the frequency range is $1-20 \mathrm{~Hz}$. It is found that when the inlet length is twice the pipe diameter, the 
inlet pulsation has no positive effect on the heat transfer. Zhuang [18] experimentally studied the effects of average Reynolds number, pulsation amplitude and dimensionless frequency on friction factor and pulsation-enhanced heat transfer. It is concluded that the larger the pulsation amplitude and the dimensionless pulsation frequency, the larger the friction factor in the transition range. The pulsating fluid will significantly affect the critical Reynolds number; the reduction of the pulsating critical Reynolds number and the laminar-turbulent cross-transformation will increase the friction factor.

\section{Experimental setup procedure}

According to the existing literature, there are three different conclusions about pulsating enhanced heat transfer, and the three conclusions are contradictory. The first conclusion is that the pulsating flow has a positive effect on the heat transfer enhancement, and the second conclusion is: the pulsating flow weakening the heat transfer; the third conclusion is that the pulsating flow does not enhance the heat transfer effect of the heat exchange nor weaken the heat transfer. The literature also shows that the difference in the position of the pulsation generator have different effect for enhanced heat transfer. In this experiment, the pulsation generator is installed at the downstream position of the heat exchange system, and the influence of the pulsating flow on the heat transfer characteristics of the plate heat exchanger is measured under the low frequency condition of the pulsation generator.

As shown in Figure 1, there is an experimental system diagram with pulsation. The main components of the whole system are plate heat exchanger A, plate heat exchanger B, electric heater 15 , hot water side circulation pump 6 , and cold side circulation pump 4 , water. Tank 3 , etc. It can be seen from the above figure that the plate heat exchanger $\mathrm{A}$ and the plate heat exchanger $\mathrm{B}$ are connected in series, the cold water outlet of the plate heat exchanger $\mathrm{A}$ is connected with the cold water inlet of the plate heat exchanger B, Install temperature sensor at the inlet and outlet of cold and hot water in the plate heat exchanger, while the plate heat exchanger B is only passed through cold water. The plate heat exchanger A, the electric heater 15 , the hot water system circulation pump 6, and the plate heat exchanger A are sequentially connected in the hot water system to form a closed circulation system. In the cold water system, the plate heat exchanger A and the plate heat exchanger B are sequentially connected, and the pulsation generator 5 is installed at the cold water outlet of the plate heat exchanger, and the cold water flows out from the water tank 3 , and enters the plate heat exchange through the cold side circulating water pump 4 . The plate A and the plate heat exchanger B are finally discharged, and the water in the pool 3 is replenished with tap water.

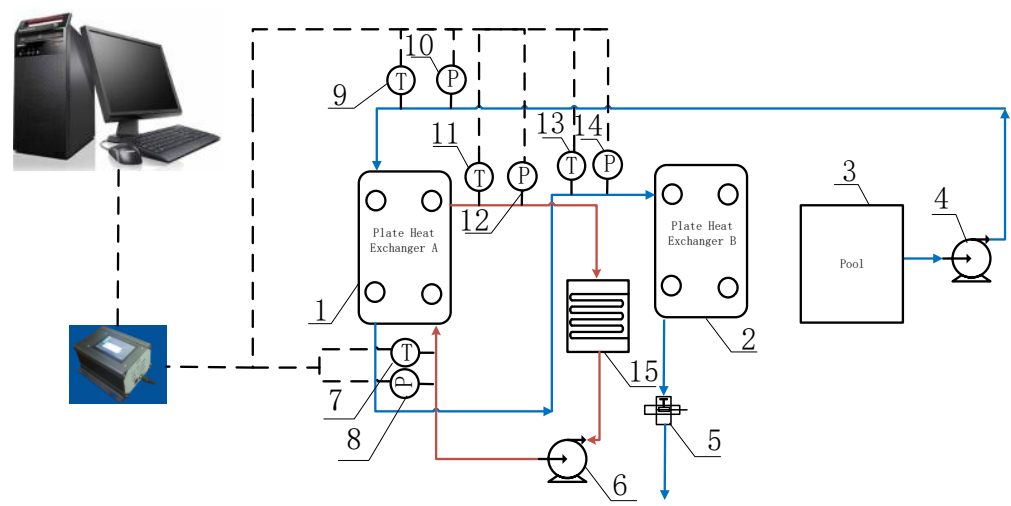

Figure 1. Pulsating generator experimental system diagram: 1 - Plate heat exchanger A, 2 - plate heat exchanger B, 3 - water tank, 4 - cold side circulating water pump, 5 - pulse generator, 6 - hot water system circulation pump, 7 - temperature sensor, 8 - pressure Sensor, 9 - temperature sensor, 10 - pressure sensor, 11 - temperature sensor, 12 - pressure sensor, 13 - temperature sensor, 14 pressure sensor, 15 - electric heater. 
The flow direction of the hot and cold fluid between the heat exchanger plates of the plate heat exchanger is shown in Figure 2. We can also find that the cold and hot fluids exchange heat in the form of counterflow in the plate heat exchanger.

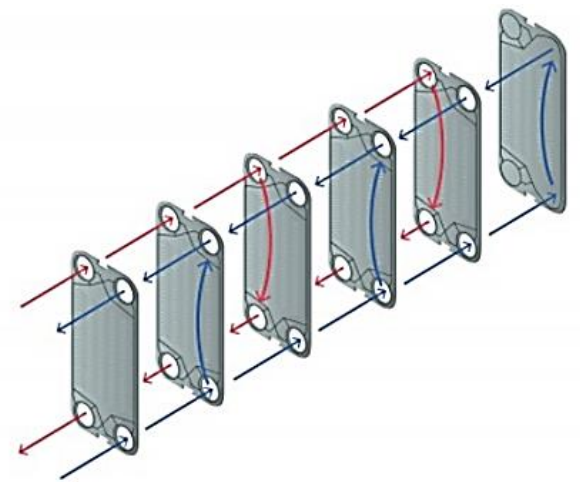

Figure 2. Corrugated plate combination and water flow direction.

In this experiment, a plate heat exchanger of the type HHNo04 was used, and the relevant physical parameters of the heat exchange plates are listed in Table. The plate heat exchanger has a total of 13 heat exchanger plates, six cold channels and six hot channels.

GEOMETRICAL CHARACTERISTICS OF CHEVRON PLATE

Table.

\begin{tabular}{ccc}
\hline Number & Particulars & Dimensions \\
\hline 1 & Port diameter, $\mathrm{d}_{\mathrm{p}}$ & $0.032 \mathrm{~m}$ \\
2 & Port to port length, $\mathrm{L}_{\mathrm{ch}}$ & $0.381 \mathrm{~m}$ \\
3 & Port to port width, $\mathrm{L}_{\mathrm{w}}$ & $0.07 \mathrm{~m}$ \\
4 & Corrugation pitch $\mathrm{p}$ & $0.011 \mathrm{~m}$ \\
5 & The amplitude of corrugation, $\mathrm{b}$ & $0.0028 \mathrm{~m}$ \\
6 & The thickness of plate, $\mathrm{t}$ & $0.0005 \mathrm{~m}$ \\
7 & Chevron angle, $\beta$ & $60^{\circ}$ \\
8 & Heat transfer area (plate) & $0.04 \mathrm{~m}^{2}$ \\
9 & Plate material & AISI 316 (Stainless steel) \\
10 & Gasket m aterial & Nitrile rubber \\
\hline
\end{tabular}

\section{Data reduction}

Reynolds number A dimensionless number that can be used to characterize the fluid flow.The Reynolds number can be used to distinguish whether the flow of a fluid is laminar or turbulent, and can also be used to determine the resistance to the flow of an object in a fluid.

$$
R e=\frac{V D_{e}}{v}
$$

where $v$ is Kinematic viscosity, $\mathrm{m}^{2} / \mathrm{s}$;

$\mathrm{V}$ is the velocity of the fluid, $\mathrm{m} / \mathrm{s}$;

$\mathrm{D}_{\mathrm{e}}$ isthe hydraulic diameter, $\mathrm{m}$.

The characteristic length of the channel was the equivalent diameter, which is defined as follows [19]:

$$
D_{e}=\frac{4 b L_{w}}{2\left(b+L_{w} \varphi\right)} \approx \frac{2 b}{\varphi}
$$


where $\varphi$ is the enlargement factor;

$\mathrm{b}$ is the amplitude of corrugation, $\mathrm{m}$;

$\mathrm{L}_{\mathrm{w}}$ is port to port width, $\mathrm{m}$;

The inlet port velocity is evaluated as:

$$
V=\frac{V_{\text {pipe }}}{A_{\text {across }} \cdot n}
$$

where $V_{\text {pipe }}$ is inlet volume flow rate, $\mathrm{m}^{3} / \mathrm{s}$;

$A_{\text {across }}$ is the inlet sectional area, $\mathrm{m}^{2}$;

$n$ is the number of channels per pass;

The logarithmic mean temperature difference

$$
\Delta t_{m}=\frac{\Delta t_{\max }-\Delta t_{\min }}{\ln \left(\frac{\Delta t_{\max }}{\Delta t_{\text {min }}}\right)}
$$

where $t_{\max } t_{\min }$ are a temperature difference of heat exchanger port, $\mathrm{K}$;

In the heat transfer at the fluid boundary (surface), the Nusselt number $(\mathrm{Nu})$ is the ratio of convective heat to conduction heat across the boundary. It is given by:

$$
N u=\frac{h D_{e}}{\lambda}
$$

where $h$ is the convective heat transfer coefficient, $\mathrm{w} /\left(\mathrm{m}^{2} \bullet \mathrm{k}\right)$;

$\lambda$ is the thermal conductivity, $\mathrm{w} /(\mathrm{m} \bullet \mathrm{k})$;

$\mathrm{D}_{\mathrm{e}}$ is the hydraulic diameter, $\mathrm{m}$;

Define convective heat transfer enhancement factor $\mathrm{E}_{\mathrm{m}}$ :

$$
E_{m}=\frac{N u_{p}}{N u_{s}}
$$

where $N u_{p}$ is the Nusselt number under pulsating flow;

$N u_{s}$ is the Nusselt number under steady state flow;

The heat transfer heat of the plate heat exchanger is calculated as:

$$
Q=C_{p} \cdot g_{1} \cdot \Delta t
$$

where Q Heat released by hot water, W;

$\mathrm{C}_{\mathrm{p}}$ is constant pressure specific heat capacity, $\mathrm{kJ} /(\mathrm{kg} \bullet \mathrm{k})$;

giismass flow, $\mathrm{Kg} / \mathrm{s}$;

$\Delta \mathrm{t}_{1}$ Hot water side inlet and outlet temperature difference, $\mathrm{K}$; 
According to the conservation of heat, the heat transfer coefficient of the plate heat exchanger is calculated as:

$$
k_{1}=\frac{Q}{A \cdot \Delta t_{m}}
$$

where $\mathrm{A}$ is heat transfer surface area, $\mathrm{m}^{2}$;

According to the principle of heat conservation and the known heat exchange area and average logarithmic temperature difference, we can calculate the convective heat transfer coefficient on the cold-water side of the plate heat exchanger and the mass flow rate on the coldwater side.

$$
g_{2}=\frac{C_{p} \cdot g_{1} \cdot \Delta t_{1}}{C_{p} \cdot \Delta t_{2}}
$$

where $\mathrm{A}$ is heat transfer surface area, $\mathrm{m}^{2}$;

$\Delta \mathrm{t}_{2}$ is cold water side inlet and outlet temperature difference, $\mathrm{K}$.

Results and discussion

The variation of heat transfer coefficient of three different mass flows at different pulsation frequencies is shown in Figure 3.

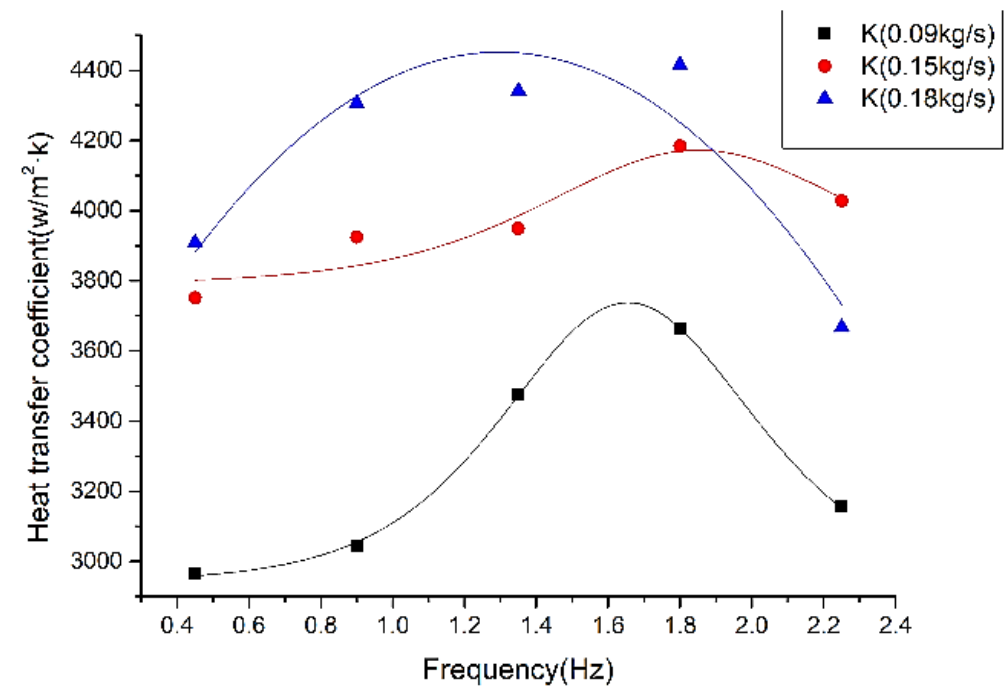

Figure 3. Heat transfer coefficient at different frequencies.

It can be seen from Figure 3 when the frequency is constant, the larger the mass flows the larger the heat transfer coefficient, and the heat transfer coefficient increases first and then decreases with the increase of frequency at the same mass flow. When the frequency is less than $1.78 \mathrm{~Hz}$, the heat transfer coefficient increases with the frequency, and when the frequency is more than $1.78 \mathrm{~Hz}$, the heat transfer coefficient decreases with frequency. We can also conclude that the heat transfer coefficient is the biggest one corresponding to the frequency of $1.78 \mathrm{~Hz}$, so the frequency of $1.78 \mathrm{~Hz}$ is optimal frequency.

Figure 4 shows that when the pulsation frequency is $1.78 \mathrm{~Hz}$, the heat transfer coefficient increases with the mass flow. When the pulsation frequency is $2.23 \mathrm{~Hz}$, the heat transfer coefficient 
increases first and then decreases with the mass flow, when the mass flow is less than $0.155 \mathrm{~kg} / \mathrm{s}$, higher pulsating frequency corresponding to higher heat transfer coefficient, when the mass flow is more than $0.155 \mathrm{~kg} / \mathrm{s}$, higher pulsating frequency corresponding to less heat transfer coefficient.

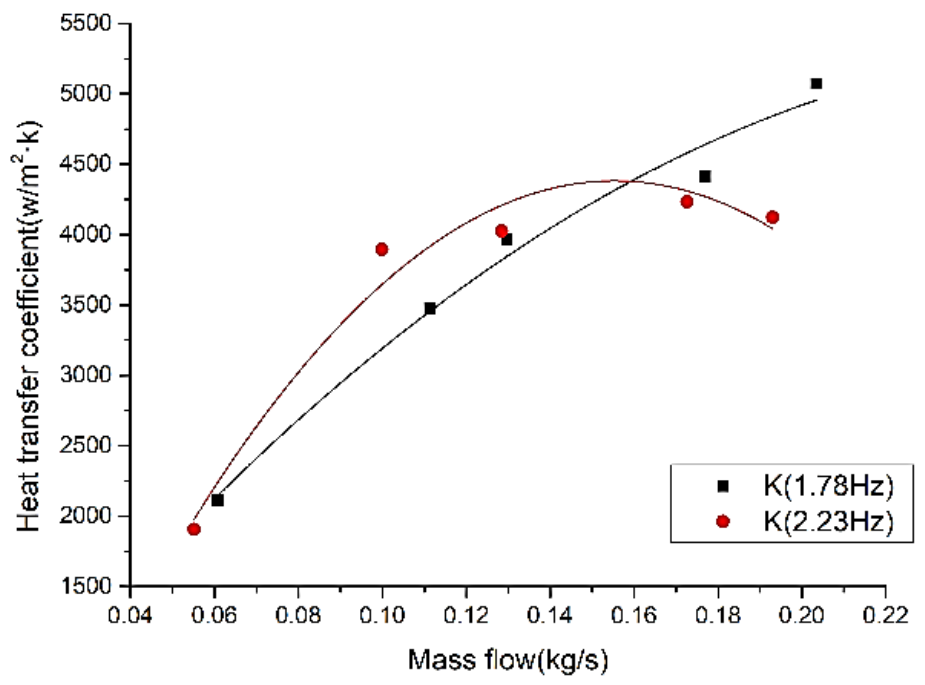

Figure 4. Heat transfer coefficient at a different mass flow.

The tendency of the Nusselt number and the mass flow is shown in Figure 5, we can find that the Nusselt number increase with the mass flow. From the Figure 4 we find when the pulsating frequency is $2.23 \mathrm{~Hz}$, the heat transfer coefficient increase first then decrease with the mass flow, Figure 5 shows the Nusselt number increase with mass flow, but when the mass flow more than $0.155 \mathrm{~kg} / \mathrm{s}$ he trend of the Nusselt number changes more gently, the Nusselt number at $1.78 \mathrm{~Hz}$ is greater than the Nusselt number at $2.23 \mathrm{~Hz}$. This phenomenon is corresponding to Figure 4.When the mass flow is less than $0.155 \mathrm{~kg} / \mathrm{s}$, the ratio of the Nusselt number at $2.23 \mathrm{~Hz}$ and Nusselt number at $1.78 \mathrm{~Hz}$ is more than 1 , indicating that the $2.23 \mathrm{~Hz}$ pulsation frequency enhancement effect is better than the $1.78 \mathrm{~Hz}$ reinforcement effect, when the mass flow is greater than $0.155 \mathrm{~kg} / \mathrm{s}$, the ratio of the Nusselt number at $2.23 \mathrm{~Hz}$ and Nusselt number at $1.78 \mathrm{~Hz}$ is less than 1 , indicating that the enhanced heat transfer effect at $1.78 \mathrm{~Hz}$ is better than the $2.23 \mathrm{~Hz}$ enhanced heat transfer effect.

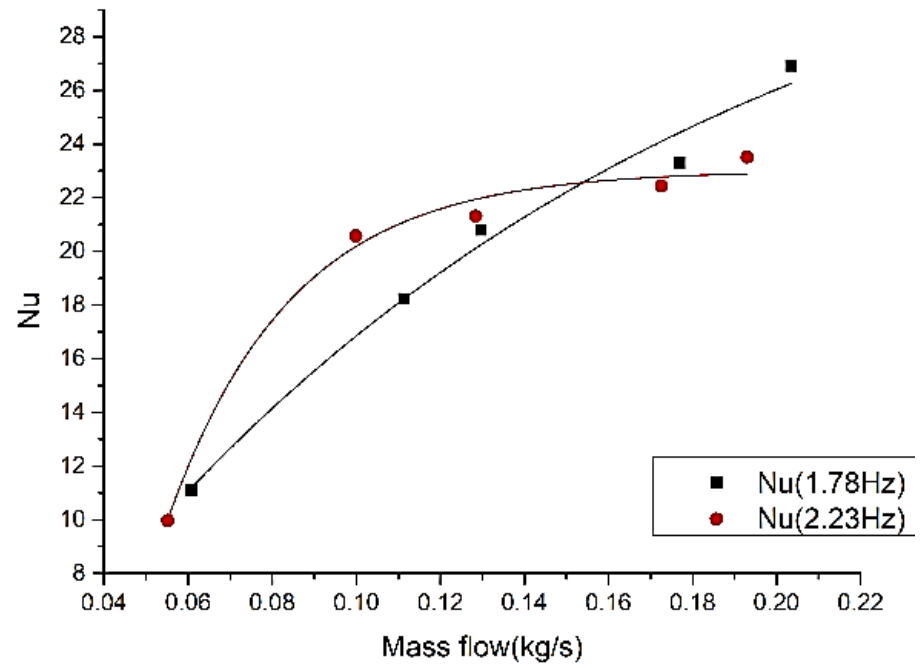

Figure 5. The Nusselt number at a different mass flow. 
From the Figure 3, we find when the pulsating frequency at $1.78 \mathrm{~Hz}$ and the mass flow at $0.155 \mathrm{~kg} / \mathrm{s}$ the heat transfer coefficient is maximum, so comparing the flow of pulsating frequency at $1.78 \mathrm{~Hz}$ with a steady flow, which shows in Figure 6. The Nusselt number under steady condition is always less than the Nusselt number at $1.78 \mathrm{~Hz}$, which means the ratio of the Nusselt number with pulsation with Nusselt number without pulsation is more than one indicating pulsating flow has a positive effect on enhanced heat transfer.

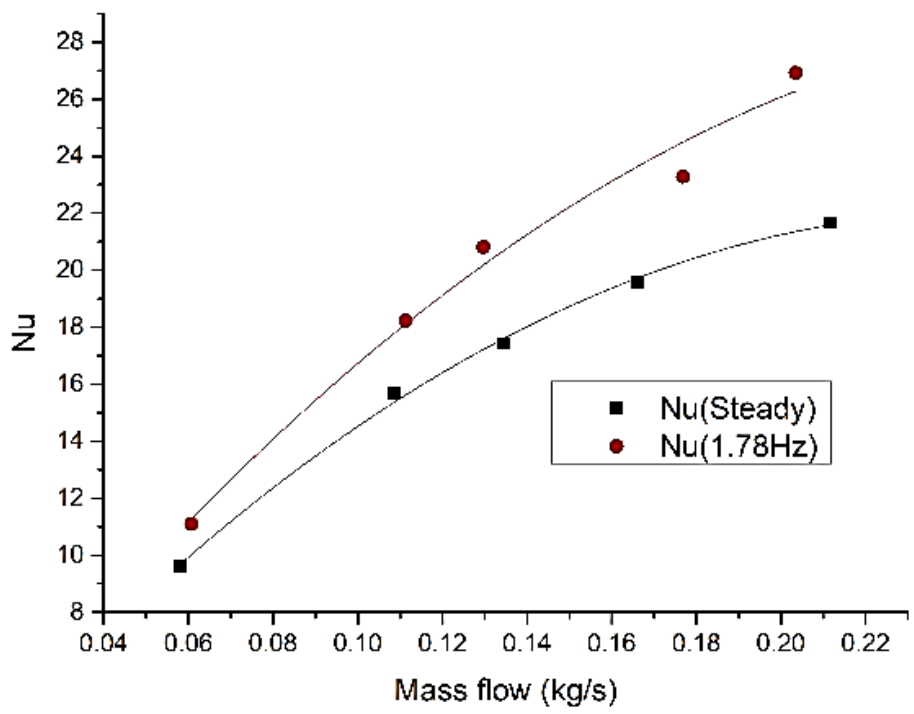

Figure 6. Nusselt number in steady state and pulsation state.

\section{Conclusion}

By comparing the two different flow patterns of steady flow and pulsating flow to the heat transfer characteristics of the plate heat exchanger, we conclude that the pulsed fluid will enhance the heat transfer effect on the plate heat exchanger; we also change the different pulsating frequency to investigate the effect of different pulsating frequency on the heat transfer characteristics of plate heat exchangers, we found that

When the pulsating frequency is less than $1.78 \mathrm{~Hz}$, the heat transfer coefficient increases with the mass flow, when the pulsation frequency is more than $1.78 \mathrm{~Hz}$, the heat transfer coefficient decreases regardless with the mass flow. Through experimental research, it is found that the pulsation frequency is $1.78 \mathrm{~Hz}$, which is the best pulsation-enhanced heat transfer frequency. When the pulsation frequency is $2.23 \mathrm{~Hz}$ and the mass flow no more than $0.155 \mathrm{~kg} / \mathrm{s}$, the heat transfer coefficient of the plate heat exchanger is greater than the heat transfer coefficient at $1.78 \mathrm{~Hz}$. When the mass flow is greater than $0.155 \mathrm{~kg} / \mathrm{s}$, the heat transfer coefficient of the plate heat exchanger at $1.78 \mathrm{~Hz}$ is much larger than that of the plate heat exchanger at $2.23 \mathrm{~Hz}$.

\section{References:}

1. Rahgoshay, M., Ranjbar, A. A., \& Ramiar, A. (2012). Laminar pulsating flow of nanofluids in a circular tube with isothermal wall. International Communications in Heat and Mass Transfer, 39(3), 463-469. https://doi.org/10.1016/j.icheatmasstransfer.2011.12.008

2. Davletshin, I. A., Mikheev, N. I., Paereliy, A. A., \& Gazizov, I. M. (2019). Convective heat transfer in the channel entrance with a square leading edge under forced flow pulsations. International Journal of Heat and Mass Transfer, 129, 74-85. https://doi.org/10.1016/j.ijheatmasstransfer.2018.09.066 
3. Jafari, M., Farhadi, M., \& Sedighi, K. (2013). Pulsating flow effects on convection heat transfer in a corrugated channel: A LBM approach. International Communications in Heat and Mass Transfer, 45, 146-154. https://doi.org/10.1016/j.icheatmasstransfer.2013.04.006

4. Zohir, A. E. (2011). The influence of pulsation on heat transfer in a heat exchanger for parallel and counter water flows. New York Science Journal, 4(6), 61-71.

5. Wantha, C. (2016). Effect and heat transfer correlations of finned tube heat exchanger under unsteady pulsating flows. International Journal of Heat and Mass Transfer, 99, 141-148. https://doi.org/10.1016/j.ijheatmasstransfer.2016.03.102

6. Zohir, A. E., Aziz, A. A. A., \& Habib, M. A. (2015). Heat transfer characteristics and pressure drop of the concentric tube equipped with coiled wires for pulsating turbulent flow. Experimental Thermal and Fluid Science, 65, 41-51. https://doi.org/10.1016/j.expthermflusci.2015.03.003

7. Witte, A., \& Polifke, W. (2017). Dynamics of unsteady heat transfer in pulsating flow across a cylinder. International Journal of Heat and Mass Transfer, 109, 1111-1131. https://doi.org/10.1016/j.ijheatmasstransfer.2017.02.072

8. Li, G., Zheng, Y., Hu, G., Zhang, Z., \& Xu, Y. (2016). Experimental study of the heat transfer enhancement from a circular cylinder in laminar pulsating cross-flows. Heat Transfer Engineering, 37(6), 535-544. https://doi.org/10.1080/01457632.2015.1060758

9. Mikheev, N. I., Molochnikov, V. M., Mikheev, A. N., \& Dushina, O. A. (2017). Hydrodynamics and heat transfer of pulsating flow around a cylinder. International Journal of Heat and Mass Transfer, 109, 254-265. https://doi.org/10.1016/j.ijheatmasstransfer.2017.01.125

10. Selimefendigil, F., \& Oztop, H. F. (2014). Control of laminar pulsating flow and heat transfer in backward-facing step by using a square obstacle. Journal of Heat Transfer, 136(8), 081701. https://doi.org/10.1115/1.4027344

11. Nandi, T. K., \& Chattopadhyay, H. (2014). Numerical investigations of developing flow and heat transfer in raccoon type microchannels under inlet pulsation. International Communications in Heat and Mass Transfer, 56, 37-41. https://doi.org/10.1016/j.icheatmasstransfer.2014.04.017

12. Shuai, X., Cheng, S., \& Antonini, G. (1994). Amelioration du transfert convectif de chaleur par l'écoulement pulse dans un fluide visqueux. The Canadian Journal of Chemical Engineering, 72(3), 468-475. https://doi.org/10.1002/cjce.5450720312

13. West, F. B., \& Taylor, A. T. (1952). The effect of pulsations on heat transfer-turbulent flow of water inside tubes. Chemical Engineering Progress, 48(1), 39-43.

14. Darling, G. B. (1959). Heat transfer to liquids in intermittent flow. Petroleum, 22, 177.

15. Zhang, H., Li, S., Cheng, J., Zheng, Z., Li, X., \& Li, F. (2018). Numerical study on the pulsating effect on heat transfer performance of pseudo-plastic fluid flow in a manifold microchannel heat sink. Applied Thermal Engineering, 129, 1092-1105. https://doi.org/10.1016/j.applthermaleng.2017.10.124

16. Mehta, B., \& Khandekar, S. (2015). Local experimental heat transfer of single-phase pulsating laminar flow in a square mini-channel. International Journal of Thermal Sciences, 91, 157-166. https://doi.org/10.1016/j.ijthermalsci.2015.01.008

17. Chattopadhyay, H., Durst, F., \& Ray, S. (2006). Analysis of heat transfer in simultaneously developing pulsating laminar flow in a pipe with constant wall temperature. International communications in heat and mass transfer, 33(4), 475-481. https://doi.org/10.1016/j.icheatmasstransfer.2005.12.008 
18. Zhuang, N., Tan, S., \& Yuan, H. (2016). The friction characteristics of low-frequency transitional pulsatile flows in narrow channel. Experimental Thermal and Fluid Science, 76, 352364. https://doi.org/10.1016/j.expthermflusci.2016.03.030

19. Imran, M., Pambudi, N. A., \& Farooq, M. (2017). Thermal and hydraulic optimization of plate heat exchanger using multi objective genetic algorithm. Case studies in thermal engineering, 10, 570-578. https://doi.org/10.1016/j.csite.2017.10.003

\section{Список литературы:}

1. Rahgoshay M., Ranjbar A. A., Ramiar A. Laminar pulsating flow of nanofluids in a circular tube with isothermal wall // International Communications in Heat and Mass Transfer. 2012. V. 39. №3. P. 463-469. https://doi.org/10.1016/j.icheatmasstransfer.2011.12.008

2. Davletshin I. A. et al. Convective heat transfer in the channel entrance with a square leading edge under forced flow pulsations // International Journal of Heat and Mass Transfer. 2019. V. 129. P. 74-85. https://doi.org/10.1016/j.ijheatmasstransfer.2018.09.066

3. Jafari M., Farhadi M., Sedighi K. Pulsating flow effects on convection heat transfer in a corrugated channel: A LBM approach // International Communications in Heat and Mass Transfer. 2013. V. 45. P. 146-154. https://doi.org/10.1016/j.icheatmasstransfer.2013.04.006

4. Zohir A. E. The influence of pulsation on heat transfer in a heat exchanger for parallel and counter water flows // New York Science Journal. 2011. V. 4. №6. P. 61-71. http://www.sciencepub.net/newyork

5. Wantha C. Effect and heat transfer correlations of finned tube heat exchanger under unsteady pulsating flows // International Journal of Heat and Mass Transfer. 2016. V. 99. P. 141148. https://doi.org/10.1016/j.ijheatmasstransfer.2016.03.102

6. Zohir A. E., Aziz A. A. A., Habib M. A. Heat transfer characteristics and pressure drop of the concentric tube equipped with coiled wires for pulsating turbulent flow // Experimental Thermal and Fluid Science. 2015. V. 65. P. 41-51. https://doi.org/10.1016/j.expthermflusci.2015.03.003

7. Witte A., Polifke W. Dynamics of unsteady heat transfer in pulsating flow across a cylinder // International Journal of Heat and Mass Transfer. 2017. V. 109. P. 1111-1131. https://doi.org/10.1016/j.ijheatmasstransfer.2017.02.072

8. Li G. et al. Experimental study of the heat transfer enhancement from a circular cylinder in laminar pulsating cross-flows // Heat Transfer Engineering. 2016. V. 37. №6. P. 535-544. https://doi.org/10.1080/01457632.2015.1060758

9. Mikheev N. I. et al. Hydrodynamics and heat transfer of pulsating flow around a cylinder // International Journal of Heat and Mass Transfer. 2017. V. 109. P. 254-265. https://doi.org/10.1016/j.ijheatmasstransfer.2017.01.125

10. Selimefendigil F., Oztop H. F. Control of laminar pulsating flow and heat transfer in backward-facing step by using a square obstacle // Journal of Heat Transfer. 2014. V. 136. №8. P. 081701. https://doi.org/10.1115/1.4027344

11. Nandi T. K., Chattopadhyay H. Numerical investigations of developing flow and heat transfer in raccoon type microchannels under inlet pulsation // International Communications in Heat and Mass Transfer. 2014. V. $56 . \quad$ P. https://doi.org/10.1016/j.icheatmasstransfer.2014.04.017

12. Shuai X., Cheng S., Antonini G. Amelioration du transfert convectif de chaleur par l'écoulement pulse dans un fluide visqueux // The Canadian Journal of Chemical Engineering. 1994. V. 72. №3. P. 468-475. https://doi.org/10.1002/cjce.5450720312

13. West F. B., Taylor A. T. The effect of pulsations on heat transfer-turbulent flow of water inside tubes // Chemical Engineering Progress. 1952. V. 48. №1. P. 39-43. 
14. Darling G. B. Heat transfer to liquids in intermittent flow // Petroleum. 1959. V. 22. P. 177.

15. Zhang H. et al. Numerical study on the pulsating effect on heat transfer performance of pseudo-plastic fluid flow in a manifold microchannel heat sink // Applied Thermal Engineering. 2018. V. 129. P. 1092-1105. https://doi.org/10.1016/j.applthermaleng.2017.10.124

16. Mehta B., Khandekar S. Local experimental heat transfer of single-phase pulsating laminar flow in a square mini-channel // International Journal of Thermal Sciences. 2015. V. 91. P. 157-166. https://doi.org/10.1016/j.ijthermalsci.2015.01.008

17. Chattopadhyay H., Durst F., Ray S. Analysis of heat transfer in simultaneously developing pulsating laminar flow in a pipe with constant wall temperature // International communications in heat and mass transfer. 2006. V. 33. №4. $P$. 475-481. https://doi.org/10.1016/j.icheatmasstransfer.2005.12.008

18. Zhuang N., Tan S., Yuan H. The friction characteristics of low-frequency transitional pulsatile flows in narrow channel // Experimental Thermal and Fluid Science. 2016. V. 76. P. 352364. https://doi.org/10.1016/j.expthermflusci.2016.03.030

19. Imran M., Pambudi N. A., Farooq M. Thermal and hydraulic optimization of plate heat exchanger using multi objective genetic algorithm // Case studies in thermal engineering. 2017. V. 10. P. 570-578. https://doi.org/10.1016/j.csite.2017.10.003

Работа поступила

Принята к публикации

в редакиию 30.06 .2019 г.

Ссылка для циитирования:

Qian H., Kudashev S., Plotnikov V. Experimental Study on Heat Transfer of Pulsating Flow Enhanced the Plate Heat Exchanger // Бюллетень науки и практики. 2019. Т. 5. №8. С. 81-92. https://doi.org/10.33619/2414-2948/45/09

Cite as (APA):

Qian, H., Kudashev, S., \& Plotnikov, V. (2019). Experimental study on heat transfer of pulsating flow enhanced the plate heat exchanger. Bulletin of Science and Practice, 5(8), 81-92. https://doi.org/10.33619/2414-2948/45/09 